\title{
Physical activity program using active video games with sedentary adolescents
}

\author{
Programa de atividade física usando vídeo jogos ativos com adolescentes sedentários \\ Programa de actividad física utilizando videojuegos activos con adolescentes sedentarios
}

Received: 11/29/2021 | Reviewed: 12/04/2021 | Accept: 12/11/2021| Published: 12/19/2021

\author{
Maria Luísa Melo Barbosa \\ ORCID: https://orcid.org/0000-0002-5100-7646 \\ Federal University of Alagoas, Brazil \\ E-mail: luisamelo1513@hotmail.com \\ Luís Felipe Melo Barbosa \\ ORCID: https://orcid.org/0000-0002-5501-339X \\ Federal University of Alagoas, Brazil \\ E-mail: luis.barbosa@famed.ufal.br \\ Ciane de Jesus Gomes Vieira \\ ORCID: https://orcid.org/0000-0001-6001-7582 \\ Federal University of Alagoas, Brazil \\ E-mail: cianedejesusedf@gmail.com \\ Auxiliadora Damianne P. V. Costa \\ ORCID: https://orcid.org/0000-0003-3072-8273 \\ Federal University of Alagoas, Brazil \\ E-mail: doradami@gmail.com \\ Luiz Rodrigo Augustemak de Lima \\ ORCID: https://orcid.org/0000-0003-0280-0151 \\ Federal University of Alagoas, Brazil \\ E-mail: augustemak@gmail.com \\ Mércia Lamenha Medeiros \\ ORCID: https://orcid.org/0000-0002-1776-3181 \\ Federal University of Alagoas, Brazil \\ E-mail: mercia.medeiros@famed.ufal.br
}

\begin{abstract}
Objective: the aim of our study was to assess the effect of a physical activity that uses active video games in body composition, physical fitness, cardiovascular and biochemical parameters with sedentary adolescents. Methods: a noncontrolled clinical trial design with a convenience sample of adolescents, separately, from ages ten to 17, of both genders. The intervention protocol consisted of physical activity with active video games (AVG), lasting two months, in 24 sessions, evolving into three levels (basic, intermediate and advanced) according to the maximum heart rate of the individuals. The adolescents' body composition, physical fitness, cardiovascular and biochemical parameters were assessed. Data analysis was performed with a 95\% confidence interval. Results: among the 14 adolescents that completed the physical training, we observed a improvement of muscle resistance $(\Delta=8.26 ; p=0.02)$ and decrease in post-exercise heart rate and systolic blood pressure $(\mathrm{p}<0.01)$. However, were found a non-significant decrease in body fat percentage $(\Delta=-3.83 ; \mathrm{p}=0.24)$ and strength $(\Delta=4.26 ; \mathrm{p}=0.57)$. A high level of satisfaction with the proposed activity was identified. Conclusion: a physical activity program based on AVG can reduce cardiovascular risk factors and improve muscle resistance in sedentary adolescents.
\end{abstract}

Keywords: Adolescent; Sedentary behavior; Exercise; Video games.

\begin{abstract}
Resumo
Objetivo: o objetivo do nosso estudo foi avaliar o efeito de uma atividade física que utiliza videogame ativo na composição corporal, aptidão física, parâmetros cardiovasculares e bioquímicos em adolescentes sedentários. Métodos: trata-se de um ensaio clínico não controlado com amostra de conveniência de adolescentes, de dez a 17 anos, de ambos os sexos. O protocolo de intervenção consistiu em atividade física com videogame ativo (AVG), com duração de dois meses, em 24 sessões, evoluindo em três níveis (básico, intermediário e avançado) de acordo com a frequência cardíaca máxima dos indivíduos. A composição corporal dos adolescentes, aptidão física, parâmetros cardiovasculares e bioquímicos foram avaliados. A análise dos dados foi realizada com intervalo de confiança de $95 \%$. Resultados: entre os 14 adolescentes que completaram o treinamento físico, observou-se melhora da resistência muscular $(\Delta=8,26 ; \mathrm{p}=$ $0,02)$ e diminuição da frequência cardíaca pós-exercício e da pressão arterial sistólica $(\mathrm{p}<0,01)$. Porém, foi encontrada diminuição não significativa do percentual de gordura corporal $(\Delta=-3,83 ; p=0,24)$ e força $(\Delta=4,26 ; p=0,57)$. Foi identificado um alto nível de satisfação com a atividade proposta. Conclusão: um programa de atividade física baseado no AVG pode reduzir os fatores de risco cardiovascular e melhorar a resistência muscular em adolescentes sedentários. Palavras-chave: Adolescente; Comportamento sedentário; Exercício; Jogos de vídeo.
\end{abstract}




\begin{abstract}
Resumen
Objetivo: El objetivo de nuestro estudio fue evaluar el efecto de una actividad física que utiliza videojuegos activos sobre la composición corporal, la condición física, los parámetros cardiovasculares y bioquímicos en adolescentes sedentarios. Métodos: se trata de un ensayo clínico no controlado con una muestra de conveniencia de adolescentes de 10 a 17 años de ambos sexos. El protocolo de intervención consistió en actividad física con videojuego activo (AVG), con una duración de dos meses, en 24 sesiones, evolucionando en tres niveles (básico, intermedio y avanzado) según la frecuencia cardíaca máxima de los individuos. Se evaluaron la composición corporal, el estado físico, los parámetros cardiovasculares y bioquímicos de los adolescentes. El análisis de los datos se realizó con un intervalo de confianza del 95\%. Resultados: entre los 14 adolescentes que completaron entrenamiento físico, hubo una mejoría en la resistencia muscular $(\Delta=8.26 ; \mathrm{p}=0.02)$ y una disminución en la frecuencia cardíaca post-ejercicio y la presión arterial sistólica ( $\mathrm{p}<0,01)$. Sin embargo, se encontró una disminución no significativa en el porcentaje de grasa corporal $(\Delta=-3.83 ; \mathrm{p}$ $=0.24)$ y fuerza $(\Delta=4.26 ; \mathrm{p}=0.57)$. Se identificó un alto nivel de satisfacción con la actividad propuesta. Conclusión: un programa de actividad física basado en AVG puede reducir los factores de riesgo cardiovascular y mejorar la resistencia muscular en adolescentes sedentarios.
\end{abstract}

Palabras clave: Adolescente; Comportamiento sedentario; Ejercicio; Juegos de vídeo.

\title{
1. Introduction
}

Modernity and changes in patterns of behavior were associated with lifestyle habits that demand lower energy expenditure. Nowadays, sedentary behavior, which comprises activities in which the person spends most of their time sitting down, with an energy expenditure between 1.0 and 1.5 METs, has been focused on an intervention program. Also, this behavior is usually linked to screen usage (Gabriel et al., 2012) reported as an increase by young people, that can be linked to the consumption of ultra-processed foods and to a higher caloric ingestion. Moreover, sedentary behavior was associated with exposure to unhealthy food and drink advertisements (Kenney et al., 2021; Payab et al., 2015).

Despite vast reports about the inverse relationship between active lifestyle and the presence of comorbidities, the number of sedentary young people has been growing steadily (Bezerra et al., 2020; Carlos et al., 2021). In a representative sample of a Brazilian capitals study (Cureau et al., 2016), 70.7\% of girls and 38.0\% of boys do not meet the minimum requirements of physical activity and $65 \%$ present sedentary behavior for longer than two hours a day.

Sedentary leisure activities grow in popularity, such as watching television, using smartphones, tablets, computers and video games (Gabriel et al., 2012). Due to the acceptability of electronic interfaces and the lack of interest in physical activity by adolescents, the use of active video games (AVG) can be seen as an alternative to increase energetic expenditure (Kabir et al., 2020; Park et al., 2020).

Traditional electronic games can stimulate sedentary behavior, because they are usually made to be played sitting down. Meanwhile, AVG depend on movement to execute commands and reproduce activities (Miguel et al., 2021), therefore this mode of playing videogames may decrease time spent in sedentary behavior, and consequently, impact health status (Kabir et al., 2020; Park et al., 2020). Studies regarding the use of AVG indicate improvement in oxygen consumption, increase in energy expenditure, and positive changes in heart rate reserve, when compared to sedentary video games (Monedero et al., 2014).

In this search for healthy lifestyle promotion, the appeal electronic games have, can offer an interesting alternative, when used in their active form, to fight obesity and the consequences of sedentary behavior, especially in those times of social restrictions. The aim of our study was to assess the effect of a physical activity intervention that uses active video games in body composition, physical fitness, cardiovascular and biochemical parameters with sedentary adolescents. In addition, we seek to analyze the effect of intervention protocol stratified by body mass index.

\section{Methodology}

\section{Design, Setting and Participants}

This is a non-controlled clinical trial, with a convenience sample, with adolescents enrolled in public schools, located in the vicinity of the University, ages ranging from ten to 17 years old, both genders. They were invited to participate after being 
diagnosed with sedentary behavior through the "International Physical Activity Questionnaire - IPAQ instrument" (Matsudo et al., 2012). As exclusion criteria, adolescents with neuromuscular diseases, visual or hearing deficit, who underwent a surgical procedure in the period of six months prior to the intervention, or who presented discomfort during the performance of the Lé ger test, were used. All participants were submitted to medical evaluation and a laboratory analysis was conducted in the Federal University Hospital.

All parameters were analyzed in initial assessment (pre-intervention), in final assessment (post-intervention), and also during the intervention (at the beginning and end of each session). All assessments and intervention protocol were conducted by a qualified and trained research team.

\section{Intervention}

The protocol consisted of 24 sessions of AVG, carried out three times a week, on alternate days, with 50 minutes duration, extending for eight weeks (Coknaz et al., 2019; Comeras-Chueca et al., 2020). Adolescents had individual supervision, in laboratory environments free from external influences. The sessions had progressive intensity, according to the maximum heart rate (HRmax). The basic level included light exercises (HR $=60 \%$ and $70 \%)$; intermediate $(71 \%$ and $80 \%)$; advanced $(81 \%$ and 90) (Perez, 2013).

The protocol took into account the stages and effort of the selected games and their potential to promote aerobic conditioning exercises, muscle strength and endurance, associated with a stretching program performed at the end of each session. Three games available for Xbox One $S \circledR$ with Xbox Kinect ${ }^{\circledR}$ compatibility were used: Fruit Ninja Kinect $2 \circledR$, Just Dance $2019 \circledR$ and Shape UP®.

During the intervention, data was collected at the beginning, during and at the end of the each session, such as heart rate (HR), blood pressure (BP) and subjective perception of exertion to monitor the training load, using the Table of Child Effort Rating Illustrated (Yelling et al., 2002). These cardiovascular parameters were grouped and analyzed according to the intervention levels (basic, intermediate and advanced).

\section{Outcomes}

Variables were divided into three categories: 1) Cardiovascular indicators: heart rate and oxygen peripheral saturation - verified through a Dellamed fingertip pulse oximeter, systolic and diastolic blood pressure, measured with a Premium ${ }^{\circledR}$ sphygmomanometer with an armband of 18 to $35 \mathrm{~cm}$ width and a Littmann ${ }^{\circledR}$ Classic III stethoscope, according to the Brazilian Hypertension Guidelines (Malachias MVB et al., 2016); 2) Body fat indicators: the anthropometric measurements were performed with a Lange brand scientific adipometer of $1 \mathrm{~mm}$ in scale to calculated body fat percentage through a two-fold method for boys and girls (Slaughter et al., 1988), body mass index (De Onis \& Lobstein, 2010) and waist ratio collected using anatomical landmarks as described in the literature (Cameron, 1978); 3) Physical fitness: the sum of handgrip strength (left and right), measured with a $100 \mathrm{kgf}$ Crown brand dynamometer, abdominal resistance, upper limbs resistance, performed according to guidelines set by Projeto de Esportes Brasil - PROESP-BR (Brazil Sports Project), in which were accounted for: the maximum number of repetitions per minute (Gaya, 2016) and cardiorespiratory fitness, that was determined 20-meters shuttle run, as described by Léger (Léger et al., 1988).

The PACES scale was used to monitor the level of satisfaction of adolescents during the intervention period, being reapplied every six sessions (a period of two weeks), after the exercises sessions (Paxton et al., 2008).

\section{Statistical Analysis}

The Kolmogorov Smirnov test was used to verify the normality of the sample. For the comparative analysis between 
the variables collected before and after exposure, the Student " $t$ " test was used for mean difference, with a 95\% confidence interval $(95 \% \mathrm{CI})$, the delta calculation was used to measure the overall change in the value of the averages. In addition, we sought to analyze the effect of the intervention protocol stratified by body mass index. Data was analyzed using Stata ${ }^{\circledR}$ Statistical Software, version 11 for Windows10, and graphs were constructed in Microsoft Excel 2013 for Windows10.

\section{Ethical Issues}

All participants previously signed an informed assent form and the respective guardians signed a free and informed consent term to participate in the study. Moreover, each session was conducted in the presence of the adolescent's parents or guardians. The study was approved by the research ethics committee under CAAE ${ }^{\circ}$ 15410619.0.0000.5013.

\section{Results}

The initial sample consisted of twenty adolescents, 14 of which completed the intervention protocol, of these $64 \%$ ( $\mathrm{n}=9$ ) were male and had a mean age of $13.35( \pm 2.16)$ years (Table 1$)$. There was a similarity between the initial and follow-up samples in relation to the main intervention variables. Dropouts were six adolescents $50 \%(\mathrm{n}=3)$ boys, dropouts were related to financial difficulties and musculoskeletal injuries.

Table 1: Samples of adolescents undergoing physical training with active video games in relation to the initial assessment.

\begin{tabular}{|c|c|c|c|}
\hline \multirow[t]{2}{*}{ Variable } & Total sample & $\begin{array}{c}\text { Adolescents who completed } \\
\text { the intervention }\end{array}$ & $\begin{array}{c}\text { Adolescents who did } \\
\text { not complete the } \\
\text { intervention }\end{array}$ \\
\hline & $\mathbf{N}=\mathbf{2 0}$ & $\mathrm{N}=14$ & $\mathrm{~N}=6$ \\
\hline \multicolumn{4}{|l|}{ Years of age } \\
\hline Mean \pm SD & $13,4 \pm 1,9$ & $13,3 \pm 2,1$ & $13,5 \pm 1,22$ \\
\hline \multicolumn{4}{|l|}{ Gender (\%) } \\
\hline Female & $8(40 \%)$ & $5(35,7 \%)$ & $3(50 \%)$ \\
\hline Male & $12(60 \%)$ & $9(64,3 \%)$ & $3(50 \%)$ \\
\hline \multicolumn{4}{|l|}{ Adolescent education (Years) } \\
\hline Mean \pm SD & $9,6 \pm 1,9$ & $9,5 \pm 2,0$ & $10 \pm 1,67$ \\
\hline \multicolumn{4}{|l|}{ Guardian's education } \\
\hline Illiterate & $0(0 \%)$ & $0(0 \%)$ & $0(0 \%)$ \\
\hline Primary school & $6(30 \%)$ & $3(21,43 \%)$ & $3(50 \%)$ \\
\hline Middle School & $5(25 \%)$ & $5(35,71 \%)$ & $0(0 \%)$ \\
\hline High school & $8(40 \%)$ & $5(35,71 \%)$ & $3(50 \%)$ \\
\hline University graduate & $1(5 \%)$ & $1(7,14 \%)$ & $0(0 \%)$ \\
\hline \multicolumn{4}{|l|}{ Screen time $(\%)$} \\
\hline Less than or equal to two hours & $5(25 \%)$ & $4(28,5 \%)$ & $1(16,67 \%)$ \\
\hline Greater than two hours & $15(75 \%)$ & $10(71,4 \%)$ & $5(83,33 \%)$ \\
\hline \multicolumn{4}{|c|}{ Brazil Economic Classification Criterion (\%) } \\
\hline $\mathrm{A}$ & $1(5 \%)$ & $0(0 \%)$ & $1(16,67 \%)$ \\
\hline $\mathrm{B}$ & $5(25 \%)$ & $5(35,7 \%)$ & $0(0 \%)$ \\
\hline $\mathrm{C}$ & $10(50 \%)$ & $8(57,1 \%)$ & $2(33,33 \%)$ \\
\hline D-E & $4(20 \%)$ & $1(7,2 \%)$ & $3(50 \%)$ \\
\hline
\end{tabular}

Source: Authors.

Body fat composition showed a non-significant decrease in the percentage of fat, with a tendency towards significance in the waist-hip ratio. Adolescents showed significant improvement regarding the variables of strength and arm flexion (17.42 \pm $9.89 \mathrm{rpm}$ to $25.71 \pm 7.88 \mathrm{rpm}$ ) (Table 2). Regarding cardiovascular indicators, we did not observe significant changes in the 
values of heart rate and blood pressure, in comparison of the initial assessment to the post-intervention (Table 2).

Table 2: Variables from the sample of 14 adolescents, analyzed before and after physical training with Active Videogames.

\begin{tabular}{|c|c|c|c|c|c|c|}
\hline \multirow{2}{*}{ Variable } & \multicolumn{2}{|c|}{$\begin{array}{c}\text { Pre-intervention } \\
(n=14)\end{array}$} & \multicolumn{2}{|c|}{ Post-intervention $(n=14)$} & \multirow{2}{*}{$\begin{array}{c}\text { Delta } \\
\Delta\end{array}$} & \multirow[t]{2}{*}{$\mathbf{p}$} \\
\hline & Mean & $\begin{array}{l}\text { Standard } \\
\text { deviation }\end{array}$ & Mean & Standard deviation & & \\
\hline \multicolumn{7}{|l|}{ Cardiovascular indicators } \\
\hline $\begin{array}{l}\text { Resting heart rate } \\
\text { (BPM) }\end{array}$ & 82,21 & 12,01 & 93,42 & 9,04 & 7,21 & 0,08 \\
\hline $\begin{array}{l}\text { Resting systolic blood } \\
\text { pressure }(\mathrm{mmHg})\end{array}$ & 110,92 & 8,61 & 106,28 & 8,33 & $-4,64$ & 0,15 \\
\hline $\begin{array}{l}\text { Resting diastolic blood } \\
\text { pressure }(\mathrm{mmHg})\end{array}$ & 63,42 & 10,10 & 69,26 & 7,11 & 1,00 & 0,76 \\
\hline \multicolumn{7}{|l|}{ Body composition } \\
\hline $\begin{array}{c}\text { Body fat } \\
\text { percentage }(\%)\end{array}$ & 28,47 & 9,66 & 24,64 & 7,14 & $-3,83$ & 0,24 \\
\hline $\begin{array}{l}\text { Body Mass Index } \\
\left(\mathrm{Kg} / \mathrm{m}^{2}\right)\end{array}$ & 21,48 & 4,22 & 21,41 & 4,17 & $-0,07$ & 0,96 \\
\hline Waist-hip-ratio $(\mathrm{cm})$ & 0,82 & 0,06 & 0,77 & 0,69 & $-0,05$ & 0,07 \\
\hline \multicolumn{7}{|l|}{ Physical aptitude } \\
\hline Sit-up test (RPM) & 21,85 & 7,64 & 26,28 & 8,87 & 4,15 & 0,20 \\
\hline Push up test (RPM) & 17,42 & 9,89 & 25,71 & 7,88 & 8,26 & $0,02 *$ \\
\hline $\begin{array}{l}\text { Cardiorespiratory } \\
\text { fitness }(\mathrm{ml} / \mathrm{min} / \mathrm{kg})\end{array}$ & 35,87 & 3,90 & 37,98 & 4,1 & 2,13 & 0,17 \\
\hline Handgrip strength & 50,31 & 18,39 & 54,57 & 20,70 & 4,26 & 0,57 \\
\hline \multicolumn{7}{|l|}{ Laboratory tests } \\
\hline Cholesterol LDL & 106,98 & 28,46 & 93,66 & 29,71 & $-13,32$ & 0,25 \\
\hline Cholesterol HDL & 42,57 & 4,92 & 48 & 10,09 & 5,43 & 0,08 \\
\hline Glycemic Index & 83,5 & 5,14 & 82,25 & 6,44 & $-1,25$ & 0,62 \\
\hline
\end{tabular}

Source: Authors.

The changes in each session throughout the intervention in cardiovascular indicators, considering the evolution in exercise intensity (basic, intermediate and advanced), are shown in Figure 1. The data revealed a significant reduction in the postexercise HR values (120.1-105.2 bpm, p<0.01), pre-exercise systolic BP (109.8-105.7 mmHg, p<0.01) and pre-exercise systolic BP moments $(111.0-105.9 \mathrm{mmHg}, \mathrm{p}<0.01)$, but not in HR at rest $(98.7-94.6, \mathrm{p}=0.06)$, but those were not statistically significant.

Figure 2 shows the health-related physical fitness of the adolescents in the sample, when separated by body composition. We observed an increase in the physical fitness of the 14 individuals and when analyzed according to BMI, with better response in the group of overweight adolescents compared to the eutrophic group in terms of arm muscle resistance (p<0.01) (figure 2).

During the entire intervention period, the adolescents maintained an index of satisfaction with physical activity, above $50 \%$. With an average satisfaction of $82.54 \%$ in the first evaluation and $81.75 \%$ in the final evaluation, and a $p=0,63$.

\section{Discussion}

The main findings of this non-controlled clinical trial based on AVG with sedentary adolescents were 1) improvement of muscle resistance, particularly evident in overweight subgroup; 2) decrease of cardiovascular risk factors measured along to 
the 24-session intervention. For greater effectiveness, physical training with active video games was structured with a conventional exercise protocol, providing opportunities for the playful nature of virtual games. The simple fact of using an AVG does not make the child less sedentary, compared to children who use conventional video games (Baranowski \& Frankel, 2012), so we elaborated and proposed an exercise protocol using the AVG.

Figure 1 - Cardiovascular indicators grouped by exercise intensity level, during the 24 intervention sessions.

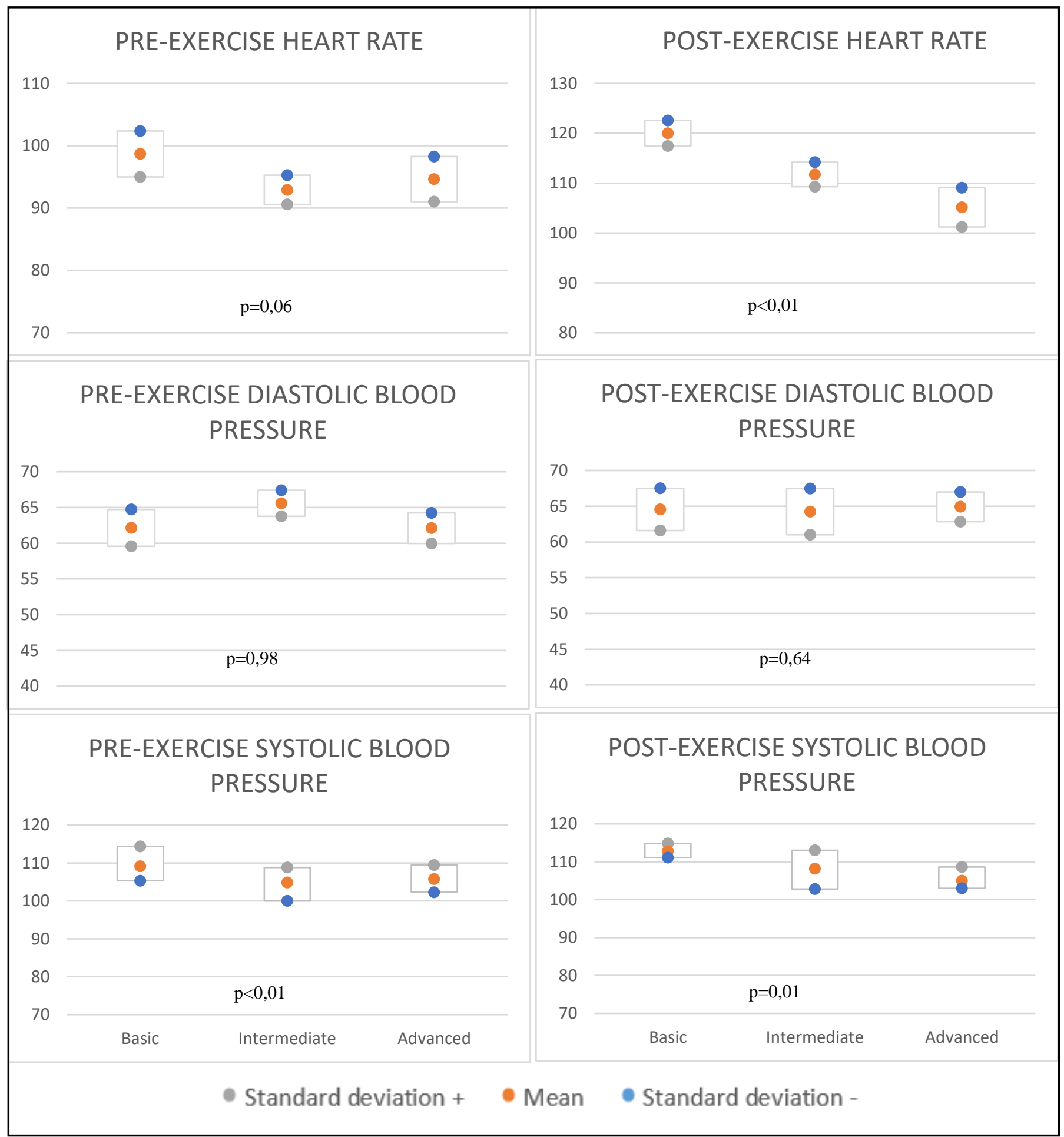

Source: Authors. 
Research, Society and Development, v. 10, n. 16, e467101624066, 2021

(CC BY 4.0) | ISSN 2525-3409 | DOI: http://dx.doi.org/10.33448/rsd-v10i16.24066

Figure 2 - Physical fitness variables of adolescents, divided by body composition.

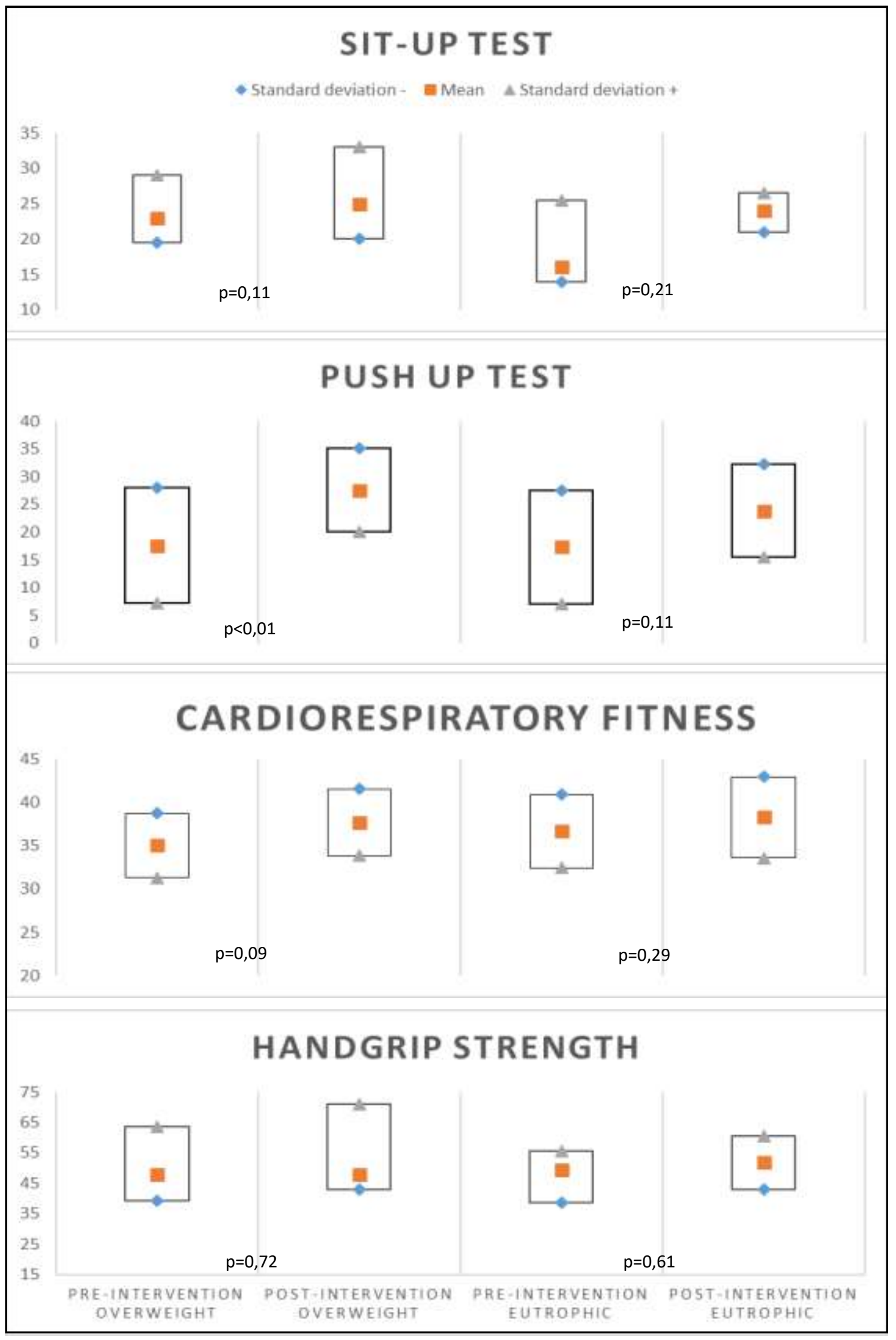

Source: Authors. 
Interventions aimed at reducing sedentary behavior are effective in reducing body composition in young people. Programs that interact with multiple sedentary activities can be as effective as multicomponent programs, with physical activity and dietary intervention, for the reduction of BMI (Liao et al., 2014). Despite the non-significant small effect of physical training with AVG on BMI, this type of intervention gains strength when used in combined approaches. Electronic games can help reduce sedentary screen time, bring motivation to adolescents through playing, understanding and adherence to healthy habits (Ameryoun et al., 2018). Furthermore, subgroup analysis showed that improvement in muscle resistance occurs in overweight sedentary adolescents $(n=7)$, but not in eutrophic peers $(n=7)$. Telemedicine was recently used for an exercise intervention; the adolescents participated in 24 sessions with an active video game, with aerobic activity protocol, in their homes. Our findings are similar to this protocol, which showed an adaptation of blood pressure and reduced body composition in adolescents (Staiano et al., 2018).

In addition to body composition, interventions based on physical activity that aim to reduce the time of sedentary behavior can benefit cardiovascular function, heart rate and blood pressure (Liao et al., 2014). Promotion of physical activity is a key component of lifestyle as a viable way of reducing BP, with reductions in SBP and DBP being observed in children aged nine to 11 years who underwent three weekly physical education classes ( $p<0.05$ ), and in overweight girls submitted to aerobic exercises for twelve weeks $(\mathrm{p}<0.05)$ (Gartlehner et al., 2020).

The intervention protocol of our study provoked physical activities of moderate and vigorous intensity, expressed by HR values and that it is already know that this accumulation is a protective factor for the development of hypertension in adolescents aged 11 to 17 years (Tozo et al., 2020). Mechanisms that regulate blood pressure through exercise include improvement of endothelial function and vasodilation; by angiogenesis; and insulin responsiveness (Gambardella et al., 2020). Acutely, this blood pressure reduction occurs through the post-exercise hypotension mechanism (Brum et al., 2004; Perrier-Melo et al., 2020; Urbana et al., 2003).

The improvement in health-related physical fitness of the adolescents in this study is in agreement with the studies by Lima et al., (de Lima et al., 2017) who reported an increase in muscle mass and flexibility in children and adolescents living with after a 24-session exercise protocol based on playful aerobic and muscle-resistance activities. Moreover, Saevarsson et al.,(Saevarsson et al., 2021) demonstrates a positive relationship between the participation of adolescents in organized sports activities and cardiorespiratory fitness, which highlights the need of appropriate activities for the participant's ages, to engage in the intervention.

Despite the benefits described, physical activities with AVG can be pointed out as a way to increase screen time due to nature of this intervention, even though this is not related to sedentary habits. However, activities with AVG are comparable to traditional exercises, being able to reach the exercise parameters regulated by the World Health Organization (Monedero et al., 2014). Furthermore, if we consider the time of exposure to sedentary screens in intervention, our sample presents a similar time to that of adolescents included in an intervention with conventional physical exercises, which was greater than two hours a day (Saevarsson et al., 2021).

\section{Conclusion}

A physical activity intervention protocol based on AVG can reduce cardiovascular risk factors and improve muscle resistance. Sedentary and overweight adolescents may experience a significant improvement in upper limb strength. A high level of satisfaction with the proposed activity was identified.

This study had some limitations, such as the choice of the sample for convenience, technical difficulties, such as limited internet connection, instability of the electrical network and the need for adequate physical installations, and sample losses. However, it was not our objective in this research to make a comparison with conventional physical training. The protocol with 
active video games managed to keep adolescents motivated to practice physical activity, proving to be a viable exercise option in their homes, especially in times such as the current one, of social distance caused by the pandemic. Also, the video games may favor social interaction among young people, through online matches, thus preserving the support network as a social determinant. Future research with a control group or different interventions, with a larger sample size, long intervention period, is needed.

\section{Acknowledgments}

We are grateful for the collaboration of Physical Education Students, Ewerton Dué and Luiz Victor Dué, for their participation during the data collection of this manuscript.

\section{Financial sources}

Coordination for the Improvement of Higher Education Personnel - CAPES, National Council for Scientific and Technological Development - CNPq, Federal University of Alagoas - UFAL.

\section{References}

Ameryoun, A., Sanaeinasab, H., Saffari, M., \& Koenig, H. G. (2018). Impact of Game-Based Health Promotion Programs on Body Mass Index in Overweight/Obese Children and Adolescents: A Systematic Review and Meta-Analysis of Randomized Controlled Trials. Childhood Obesity, 14(2), 67-80. https://doi.org/10.1089/chi.2017.0250

Baranowski, T., \& Frankel, L. (2012). Let's Get Technical! Gaming and Technology for Weight Control and Health Promotion in Children. Childhood Obesity, 8(1), 34-37. https://doi.org/10.1089/chi.2011.0103

Bezerra, M. A. A., Sousa, J. S. R., Simões Neto, J. de C., Gomes Filho, A. dos S., \& Bottcher, L. B. (2020). Prevalência de inatividade física na adolescência: revisão sistemática. Health of Humans, 2(1), 1-9. https://doi.org/10.6008/cbpc2674-6506.2020.001.0001

Brum, P. C., Forjaz, C. L. de M., Tinucci, T., \& Negrão, C. E. (2004). Adaptações agudas e crônicas do exercício físico no sistema cardiovascular. Rev Paul Educ Fís, 18(ago, n. esp.), 21-31.

Cameron, N. (1978). The Methods of Auxological Anthropometry. In Human Growth (pp. 35-90). Springer US. https://doi.org/10.1007/978-1-4684-2622-9_3

Carlos, F. de M., Borges Neto, J. de S., Bicalho, J. M. F., Oliveira, G. H., Campos, C. G., Bila, W. C., Lamounier, J. A., \& Romano, M. C. C. (2021). Adolescentes socialmente menos favorecidos estão mais sujeitos ao sedentarismo? uma revisão sistemática. Research, Society and Development, 10 (14), e305101422048. https://doi.org/10.33448/rsd-v10i14.22048

Coknaz, D., Mirzeoglu, A. D., Atasoy, H. I., Alkoy, S., Coknaz, H., \& Goral, K. (2019). A digital movement in the world of inactive children: favourable outcomes of playing active video games in a pilot randomized trial. European Journal of Pediatrics, 178(10), 1567-1576. https://doi.org/10.1007/s00431-01903457-x

Comeras-Chueca, C., Villalba-Heredia, L., Pérez-Llera, M., Lozano-Berges, G., Marín-Puyalto, J., Vicente-Rodríguez, G., Matute-Llorente, Á., Casajús, J. A., \& González-Agüero, A. (2020). Assessment of Active Video Games’ Energy Expenditure in Children with Overweight and Obesity and Differences by Gender. International Journal of Environmental Research and Public Health, 17(18), 6714. https://doi.org/10.3390/ijerph17186714

Cureau, F. V., Da Silva, T. L. N., Bloch, K. V., Fujimori, E., Belfort, D. R., De Carvalho, K. M. B., De Leon, E. B., De Vasconcellos, M. T. L., Ekelund, U., \& Schaan, B. D. (2016). ERICA: Leisure-time physical inactivity in Brazilian adolescents. Revista de Saude Publica, 50(supl 1), 1s-11s. https://doi.org/10.1590/S01518-8787.2016050006683

Lima, L. R. A., Back, I. de C., Beck, C. C., \& Caramelli, B. (2017). Exercício Melhora o Risco Cardiovascular, Aptidão Física e Qualidade de Vida em Crianças e Adolescentes Hiv+: Estudo Piloto. Int. j. Cardiovasc. Sci. (Impr.), 30(2), f:171--1:176.

Onis, M., \& Lobstein, T. (2010). Defining obesity risk status in the general childhood population: Which cut-offs should we use? International Journal of Pediatric Obesity, 5(6), 458-460. https://doi.org/10.3109/17477161003615583

Gabriel, K. K. P., Morrow, J. R., \& Woolsey, A.-L. T. (2012). Framework for Physical Activity as a Complex and Multidimensional Behavior. Journal of Physical Activity and Health, 9(s1), S11-S18. https://doi.org/10.1123/jpah.9.s1.s11

Gambardella, J., Morelli, M. B., Wang, X., \& Santulli, G. (2020). Pathophysiological mechanisms underlying the beneficial effects of physical activity in hypertension. The Journal of Clinical Hypertension, 22(2), 291-295. https://doi.org/10.1111/jch.13804

Gartlehner, G., Vander Schaaf, E. B., Orr, C., Kennedy, S. M., Clark, R., \& Viswanathan, M. (2020). Screening for Hypertension in Children and Adolescents. JAMA, 324(18), 1884. https://doi.org/10.1001/jama.2020.11119 
Gaya, A. G. A. R. (2016). Projeto Esporte Brasil: manual de testes e avaliação versão 2016. Https://Www.Ufrgs.Br/Proesp/Arquivos/Manual-Proesp-Br2016.Pdf, 25 .

Kabir, M., Dhruba, Q. F. F., Mahmud, H., Hasan, M. K., \& Zaman, A. R. (2020). Gaming Insight: Conversion of Popular Sedentary Games into Motion-Based Form. International Journal of Human-Computer Interaction, 36(13), 1205-1215. https://doi.org/10.1080/10447318.2020.1726597

Kenney, E. L., Mozaffarian, R. S., Long, M. W., Barrett, J. L., Cradock, A. L., Giles, C. M., Ward, Z. J., \& Gortmaker, S. L. (2021). Limiting Television to Reduce Childhood Obesity: Cost-Effectiveness of Five Population Strategies. Childhood Obesity, X(X), 1-7. https://doi.org/10.1089/chi.2021.0016

Léger, L. A., Mercier, D., Gadoury, C., \& Lambert, J. (1988). The multistage 20 metre shuttle run test for aerobic fitness. Journal of Sports Sciences, 6(2), 93101. https://doi.org/10.1080/02640418808729800

Liao, Y., Liao, J., Durand, C. P., \& Dunton, G. F. (2014). Which type of sedentary behaviour intervention is more effective at reducing body mass index in children? A meta-analytic review. Obesity Reviews, 15(3), 159-168. https://doi.org/10.1111/obr.12112

Malachias, M. V. B., Gomes, M. A. M., Nobre, F., Alessi, A., Feitosa, A. D., \& Coelho, E. B. (2016). $7^{\text {a }}$ Diretriz Brasileira de Hipertensão Arterial: capítulo 2diagnóstico e classificação. Arquivos Brasileiros de Cardiologia, 107, 07-13.

Matsudo, S., Araujo, T., Matsudo, V., Andrade, D., Andrade, E., Oliveira, L. C., \& Braggion, G. (2012). Questionário Internacional De Atividade Física (Ipaq): Estupo De Validade E Reprodutibilidade No Brasil. Atividade Física \& Saúde, 6(2), 5-18. https://doi.org/10.12820/rbafs.v.6n2p5-18

Miguel, G. F. de S., Sá, A. A. R. de, Souza, J. T. de, \& Naves, E. L. M. (2021). Home-based telerehabilitation: A review of remote therapy frameworks. Research, Society and Development, 10(6), e4910615489. https://doi.org/10.33448/rsd-v10i6.15489

Monedero, J., McDonnell, A. C., Keoghan, M., \& O’Gorman, D. J. (2014). Modified Active Videogame Play Results in Moderate-Intensity Exercise. Games for Health Journal, 3(4), 234-240. https://doi.org/10.1089/g4h.2013.0096

Park, S.-B., Kim, M., Lee, E., Lee, D., Son, S. J., Hong, J., \& Yang, W.-H. (2020). Energy System Contributions and Physical Activity in Specific Age Groups during Exergames. International Journal of Environmental Research and Public Health, 17(13), 4905. https://doi.org/10.3390/ijerph17134905

Paxton, R. J., Nigg, C., Motl, R. W., Yamashita, M., Chung, R., Battista, J., \& Chang, J. (2008). Physical Activity Enjoyment Scale Short Form-—Does It Fit for Children? Research Quarterly for Exercise and Sport, 79(3), 423-427. https://doi.org/10.1080/02701367.2008.10599508

Payab, M., Kelishadi, R., Qorbani, M., Motlagh, M. E., Ranjbar, S. H., Ardalan, G., Zahedi, H., Chinian, M., Asayesh, H., Larijani, B., \& Heshmat, R. (2015). Association of junk food consumption with high blood pressure and obesity in Iranian children and adolescents: the Caspian-IV Study. Jornal de Pediatria (Versão Em Português), 91(2), 196-205. https://doi.org/10.1016/j.jpedp.2014.07.008

Perez, A. J. (2013). Efeitos de diferentes modelos de periodização do treinamento aeróbio sobre parâmetros cardiovasculares, metabólicos e composição corporal de bombeiros militares. Revista Brasileira de Educação Física e Esporte, 27(3), 363-376. https://doi.org/10.1590/s1807-55092013000300004

Perrier-Melo, R. J., Costa, E. C., Farah, B. Q., \& Costa, M. da C. (2020). Efeito Agudo do Exercício Intervalado versus Contínuo sobre a Pressão Arterial: Revisão Sistemática e Metanálise. Revista Brasileira de Medicina Do Esporte, 115(1), 5-14. https://doi.org/10.36660/abc.20190107

Saevarsson, E. S., Rognvaldsdottir, V., Stefansdottir, R., \& Johannsson, E. (2021). Organized Sport Participation, Physical Activity, Sleep and Screen Time in 16-Year-Old Adolescents. International Journal of Environmental Research and Public Health, 18(6), 3162. https://doi.org/10.3390/ijerph18063162

Slaughter, A. M. H., Lohman, T. G., Boileau, R. A., Horswill, C. A., Stillman, R. J., Loan, M. D. V. A. N., \& Bemben, D. A. (1988). Skinfold Equations for Estimation of Body Fatness in Children and Youth Published by: Wayne State University Press Stable URL : http://www.jstor.org/stable/41464064 . Human Biology, 60(5), 709-723.

Staiano, A. E., Beyl, R. A., Guan, W., Hendrick, C. A., Hsia, D. S., \& Newton, R. L. (2018). Home-based exergaming among children with overweight and obesity: a randomized clinical trial. Pediatric Obesity, 13(11), 724-733. https://doi.org/10.1111/ijpo.12438

Tozo, T. A., Pereira, B. O., Menezes, F. J. de, Montenegro, C. M., Moreira, C. M. M., \& Leite, N. (2020). Medidas Hipertensivas em Escolares: Risco da Obesidade Central e Efeito Protetor da Atividade Física Moderada-Vigorosa. Arquivos Brasileiros de Cardiologia, 115(1), 42-49. https://doi.org/10.36660/abc.20180391

Urbana, M., Rondon, P. B., \& Brum, P. C. (2003). Exercício físico como tratamento não-farmacológico da hipertensão arterial. Revista Brasileira de Hipertensão, 10(11), 134-139.

Yelling, M., Lamb, K. L., \& Swaine, I. L. (2002). Validity of a Pictorial Perceived Exertion Scale for Effort Estimation and Effort Production During Stepping Exercise in Adolescent Children. European Physical Education Review, 8(2), 157-175. https://doi.org/10.1177/1356336X020082007 